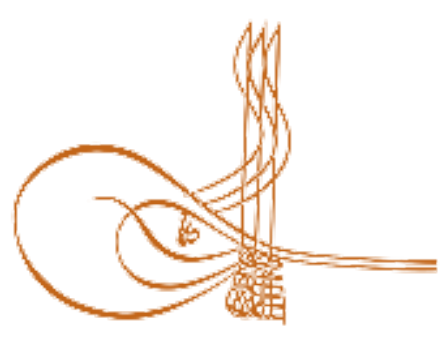

www.turkishstudies.net/education
Turkish Studies - Educational Sciences

eISSN: 2667-5609

Research Article / Araștırma Makalesi

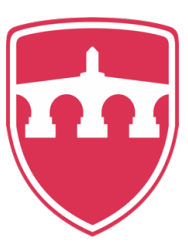

INTERNATIONAL BALKAN

UNIVERSITY

Sponsored by IBU

\title{
Başarı Testi Geliştirme: Asit-Baz Başarı Testi Geçerlik ve Güvenirlik Araştırması
}

\author{
Development of Achievement Test: A Validity and Reliability Research for Acid-Base Achievement \\ Test
}

\author{
Salih Özkan* - Mustafa Yadigaroğlu*
}

\begin{abstract}
The aim of this study is to develop a valid and reliable measurement tool to measure the students' success about Acids and Bases. In the study, first of all, a list of learning objectives was created by taking into consideration the Science Curriculum in 2018, and then the items were written in accordance with the learning objectives. Before final form of the test was obtained, the opinions of three academic experts in the field of chemistry education and two science teachers were used for the consistency of scientific information of the test items prepared and the opinions of two language experts were used for the grammar, and various arrangements were made on the test items. A pilot study of the test prepared was carried out with 10 students in the $8^{\text {th }}$ grade. The final arrangements were made on the test items by the feedbacks from the students and the final form of the Acid-Base Achievement test (ABAT) was obtained. The final form of the test was applied to 212 students of $8^{\text {th }}$ grade. Test data were analyzed using SPSS 23.0, ITEMAN 3.0. and FACTOR application. As a result of the analysis of the items with ITEMAN 3.0, the discrimination index was 0.747 and the item difficulty index was 0.496. Kuder-Richardson-20 (KR-20) was calculated to determine the internal consistency of the test using the values obtained from the item analyzes and was found to be 0.732 . FACTOR application was used to calculate the construct validity of the test and Kaiser-Meyer-Olkin (KMO) value was calculated 0.778 . When the results obtained are examined, it is seen that valid and reliable results have been obtained with the ABAT developed. As ABAT is prepared in accordance with the achievements, it is considered to be a valid and reliable measurement tool that can be used by science teachers.
\end{abstract}

Structured Abstract: Many of the events and phenomena, which are within the scope of the science course, are closely associated with daily life and are frequently encountered in all areas of life, are closely related to chemistry concepts. Although chemistry is frequently used in daily life and forms an important part of life,

\footnotetext{
*Çalışmanın Aksaray Üniversitesi İnsan Araştırmaları Etik Kurulunun 19.04.2019 tarihli 2019/03-04 kararı ile etik ilkelere uygun olduğuna karar verilmiştir (EK-1)

* Yüksek Lisans Öğrencisi, Aksaray Üniversitesi Fen Bilimleri Enstitüsü

Graduate Student, Aksaray University Graduate School of Natural and Applied Sciences

ORCID 0000-0003-3716-110X

salihzkn.6@gmail.com

** Dr. Öğr. Üyesi, Aksaray Üniversitesi, Eğitim Fakültesi, Matematik ve Fen Bilimleri Eğitimi Bölümü

Asst. Prof., Aksaray University, Faculty of Education, Department of Mathematics and Science Education

ORCID 0000-0001-8143-2339

mustafayadigaroglu@hotmail.com

Cite as/ Atıf: Özkan, S. \& Yadigaroğlu, M: (2020). Başarı testi geliştirme: asit-baz başarı testi geçerlik ve güvenirlik araştırmas1, Turkish Studies - Education, 15(2), 1141-1163. https://dx.doi.org/10.29228/TurkishStudies.41734

Received/Geliş: 12 February/Şubat 2020

Accepted/Kabul: 29 April/Nisan 2020

Checked by plagiarism software

Copyright (C) INTAC LTD, Turkey

Published/Yayın: 30 April/Nisan 2020

CC BY-NC 4.0
} 
students encounter problems while making many concepts in the subjects of the chemistry concrete in their minds (Yadigaroğlu, Demircioğlu and Demircioğlu, 2017). Acids and bases are among these subjects. Students encounter the concepts of acid and base firstly during the science course in the eighth grade. Since acid and base concepts are related to daily life and also related to the subjects that students will frequently encounter in the future learning levels, it is very important to learn the concept of acid and base by the students.

Studies related to acids and bases, which were carried out at different levels of education (primary, high school, university), in the international and national literature indicate that the majority of the students have difficulties in comprehending and understanding of the acid and base concepts. In the measurement and evaluation part of the studies, measurement tools are used to determine the achievement and conceptual understanding. The tests prepared should be directed to the problems encountered in daily life in order for the students to apply the scientific knowledge they have learned to their real life (Bennett, Lubben and Hogart, 2007). Therefore, there is a need for a valid and reliable measurement tool containing the test items associated with the daily life about acids and bases. In the studies for measuring and evaluating the students' success, two-tier tests, interview, exam, open-ended questions, true-false tests, written examinations, multiple choice tests, short-answer tests, matching tests and gap-filling tests were used in the education levels in order to measure and evaluate the students' success (Şimşek, 2007; Ogan Bekiroğlu, 2004). Multiple choice tests consisting of sections in which one or more units are contained, also consisting of a large number of questions to ensure the content validity of the subjects discussed, effectively questioning the students' learning, and providing an opportunity to measure both easy and difficult-to-understand concepts, are one of the frequently preferred measurement tools (Akbulut, Çepni, 2013).

Various international studies are carried out to evaluate the educational systems of the countries in an independent and objective manner. The most important ones of these studies are Trends in International Mathematics and Science Study (TIMSS) and Programme for International Student Assessment (PISA). TIMMS is a survey research to evaluate the students' knowledge and skills in mathematics and science (MEB, 2015). The questions prepared in these exams are created such that they will be related to daily life and will be designed to require higher level thinking skills. When the obtained results were examined in terms of our country, we see that we are not at the desired level in general. From this point of view, the aim of the study is to analyze the validity and reliability of the Acid and Base Achievement Test (ABAT) prepared for the subject acids and bases in the Substance and Industry unit of the eighth grade.

While the Acid-Base Achievement Test (ABAT) was prepared, the learning objectives determined by MoNE (2018) were taken into consideration and multiplechoice questions were enabled to be related to the learning objectives. While the test was prepared, an item pool was first created and then expert opinions were obtained to ensure the content validity of ABAT. After the expert opinions were obtained, the necessary arrangements were made, a pilot study of ABAT was performed, and the item analysis of the obtained data was performed. After the item analysis, the validity and reliability value of ABAT was determined, and the final form of the test was obtained after the items to be excluded from the test were determined.

The sample of this study is composed of 212 students of eighth grade in the central districts of Adana and Aksaray in 2018-2019 academic years. In this study, criterion sampling, one of the purposive sampling methods, was used to determine the schools of the participants.

In the study, some steps were planned and realized in order to ensure the validity and reliability of the ABAT development process about the acid-base subject. During ABAT development process, statistical analyses were performed for creating the item pool, obtaining expert opinions, performing preliminary studies and realizing validity and reliability studies. 13 of the 21 items in the test have an item discrimination index (rjx) of 0.40 and above. The item discrimination index is used to give researchers an idea of whether the desired behavior can be achieved. When the discrimination index of an item is between -1 and +1 , a value of " 0 " indicates that the item is not discriminatory. If the item discrimination index has a value of 0.19 and below, this means that the items will be excluded from the test, whereas the items having a value between 0.20 and 0.29 should be corrected or may be used in compulsory cases, the items having a value between 0.30 and 0.39 are sufficiently good and the items having a value of 0.40 and above are very good (Büyüköztürk et al., 2012; Karslı and Ayas, 2013; Tosun and Taşkesenligil, 2011). In accordance with this result, the discrimination values of ABAT were found to be high. 
The item difficulty index $(\mathrm{Pj})$ indicates the correct response rate for each item in the test, and has a value between "0" and " 1 . If the values of an item get closer to zero, it means that the item becomes difficult, whereas if the values of an item get closer to one, it means that the item becomes easy. As a result of the item analysis, it is preferred for the item difficulty indices of the items to be between 0.20 and 0.80 and the average difficulty index of the test to be about 0.50 (Büyüköztürk, Çakmak, Akgün, Karadeniz and Demirel, 2012; Tosun and Taşkesenligil, 2011). Since the item difficulty indices of the test items were around 0.50 , the item difficulty index was found to be high.

In order to ensure the construct validity of ABAT, data belonging to $27 \%$ lower and upper groups were determined and divided into two groups. As a result of this analysis, the significance of the difference between the two groups was examined and the independent groups t-test was applied. The results of the independent t-test were interpreted as follows: the items with a Sig (2-tailed) value less than 0.05 would be included in the test, and the items with a value greater than 0.05 would be excluded from the test as there was no significant difference (Yıldırım and Şimşek, 2013). The significance values of the items that were decided to be excluded from the scale were examined and $\mathrm{p}<0.05$ was found to be high. It was observed that the achievements of items that were decided to be excluded from the scale included in the table of specifications were examined that and this did not affect the content validity of the subject.

The average item difficulty index was found to be 0.522 . It is seen that the scale has average difficulty and has a near-ideal value. The average discrimination index of the scale was found to be 0.415 and this was interpreted as follows: the items could distinguish between the students who had knowledge and who did not. After the data were obtained from the item analysis, Kuder-Richardson 20 (KR-20) reliability coefficient was calculated to determine the internal consistency coefficient of the scale. Calculation according to the KR-20 formula is based on the assumption that each item in the test measures the same variable and the thing the test measured has the same properties (Tekin, 2007). The internal consistency coefficient of ABAT was calculated and found to be 0.732 . The value obtained varies between 0.00 and 1.00 . The reliability coefficient calculated for a test is between 0.80 and 1.00 , which means that the measurement tool is highly reliable, whereas if this coefficient is between 0.60 and 0.80 , then it means that the tool is highly reliable, and a value of 0.60 and below means that the reliability is low or very low (Kalayc1, 2008).

This study was composed of 19 items with four options about acids and bases in the substance and industry unit of the science course in the eighth grade and was prepared in accordance with the current curriculum. The theoretical framework of the scale consists of the free textbook, PISA, TIMSS exams, test books which are prepared in accordance with the grade level and are still being published, and books prepared specifically by the authors. In order to ensure the validity of the scale, opinions were obtained from academicians who were experts in their fields and from science teachers working in the Ministry of National Education. In order to ensure the content validity of the scale, a table of specifications was formed and expert opinions obtained to decide which target behaviors and cognitive level were suitable for it. ABAT can be used to determine students' success in the later stages and to reveal misconceptions.

Keywords: Science Education, Acids and Bases, Achievement Test, Test Development, Validity, Reliability

Öz: Bu çalışmanın amacı Asitler ve Bazlar konusunda öğrencilerin başarılarını ölçmek için geçerli ve güvenilir bir ölçüm aracı geliştirmektir. Çalışmada ilk olarak 2018 Fen Bilimleri Dersi Öğretim Programı dikkate alınarak kazanım listesi oluşturulmuştur, daha sonra kazanımlara uygun olacak şekilde maddeler yazılmıştır. Teste son hali verilmeden önce, hazırlanan test maddelerinin bilimsel bilgilerin tutarlığı açısından kimya alanında uzman üç öğretim üyesinin ve iki fen bilimleri dersi öğretmeninin, dil bilgisi açısından iki dil uzmanının görüşlerinden faydalanılmış ve test maddeleri üzerinde çeşitli düzenlemeler yapılmıştır. Çalışma 2018-2019 öğretim yılı içerisinde yapılmıştır. Hazırlanan testin, 8.sınıfta öğrenimine devam eden 10 öğrenci ile pilot çalışması gerçekleştirilmiş̧ir. Öğrencilerden gelen dönütler ile test maddeleri üzerinde son düzenlemeler yapılmış ve Asit-Baz Başarı Testine (ABBT) son hali verilmiştir. Son hali verilen test 212 sekizinci sınıf öğrencisine uygulanmıştır. Test verileri SPSS 23.0, ITEMAN 3.0 ve FACTOR uygulamaları ile analiz edilmiştir. ITEMAN 3.0 ile maddelerin analizi sonucunda ayırt edicilik indeksi 0,747 , madde güçlük indeksi ise 0,496 olarak bulunmuştur. Madde analizlerinden elde edilen değerler ile testin iç tutarlılığını belirlemek için Kuder-Richardson-20 (KR-20) hesaplanmış ve 0,732 bulunmuştur. Testin yapı geçerliliği hesaplamak için FACTOR uygulaması kullanılmış ve Kaiser-Meyer-Olkin (KMO) değeri 0,778 bulunmuştur. Elde edilen sonuçlar incelendiğinde, geliştirilen ABBT ile geçerli ve güvenilir sonuçlara 
ulaşıldığı görülmektedir. ABBT kazanımlara uygun olarak hazırlandığı için fen bilimleri öğretmenleri tarafından kullanılabilecek geçerliği ve güvenirliği sağlanmış bir ölçme aracı olduğu düşünülmektedir.

Anahtar Kelimeler: Fen Eğitimi, Asitler ve Bazlar, Başarı Testi, Test Geliştirme, Geçerlik, Güvenirlik.

\section{Giriş}

Fen bilimleri dersi içerisinde yer alan, günlük hayatla yakından ilişkili olan ve yaşamın her alanında sıklıkla karşılaşılan olay ve olguların birçoğu kimya kavramları ile yakından ilişkilidir. Kimya, günlük hayatta sıkça kullanılmasına ve hayatın önemli bir kısmını oluşturmasına rağmen öğrenciler kimya konuları içerisinde yer alan birçok kavramı zihinlerinde somut hale getirirken sorunlarla karşılaşmaktadır (Yadigaroğlu, Demircioğlu ve Demircioğlu, 2017). Bu konuların arasında asitler ve bazlar da yer almaktadır. Öğrenciler asit ve baz kavramları ile ilk olarak Fen bilimleri dersi kapsamında sekizinci sınıfta karşılaşmaktadırlar. Asit ve baz kavramları günlük hayatla ilişkili olan bir konu olması ve ilerideki öğrenme kademelerinde öğrencilerin sıkça karşılaşacakları konular ile ilişkili olmasından dolayı bu kavramların öğrenciler tarafindan öğrenilmesi oldukça önemlidir. Çünkü öğrencilerin sahip oldukları öğrenme deneyimleri sonucunda elde ettikleri yanlış kavramalar ve ön bilgiler öğrencilerin sonraki öğrenmeleri üzerine etki ettiği bilinmektedir (Andersson, 1986; Griffiths ve Preston, 1992; Saunders ve Shepardson, 1987).

Uluslararası ve ulusal alan yazında asitler ve bazlar konusu ile ilgili farklı öğretim kademelerinde (ilköğretim, lise, üniversite) gerçekleştirilen çalışmalar, öğrencilerin büyük çoğunluğunun asit ve baz kavramlarını kavramada ve anlamada zorluklar yaşadığını göstermektedir (Avcı Bölek, 2012; Bradley ve Mosimege, 1998; Canpolat, Pınarbaş1, Bayrakçeken ve Geban, 2004; Cooper ve Peterson, 2012; Corcoran, Mosher ve Rogat, 2009; Çavdar, Okumuş, Alyar ve Doymuş, 2017; Çelikler ve Harman, 2015; Çökelez, 2015; Demirci ve Özmen, 2012; Demircioğlu, Özdemir, Özmen, Cındıl ve Yıldız, 2012; Özmen, Demircioğlu ve Coll, 2007; Pabuçcu ve Geban, 2015; Smith ve Metz, 1996; Tsaparlis, 1997).

Öğrencilerin öğrendikleri bilimsel bilgileri gerçek hayatlarında da uygulayabilmesi (Bennett, Lubben ve Hogart, 2007) için hazırlanan ölçme araçlarının gündelik hayatta karşılaştığ sorunlara yönelik olması gerekmektedir. Bu nedenle asitler ve bazlar konusunda geçerli ve güvenilir ayrıca günlük hayatla ilişki soru maddelerini içeren bir ölçme aracına ihtiyaç duyulmaktadır. Alan yazın incelenmesin yapılan çalışmalarda ölçme araçlarının genellikle başarı ve kavramsal anlamayı belirlemeye yönelik olduğu görülmektedir.

Günlük yaşamda bireyler sıkça yeni olaylar ve problemlerle karşılaşmaktadır. Ancak bu durumların bazılarının sonucunda eksik ya da yanlış öğrenmeler meydana gelebilmektedir. Bireylere verilen eğitim sonucunda beklenen, istendik davranışları edinip edinmediklerini belirlemektir. Bunun sağlanabilmesi için geçerliği ve güvenirliği sağlanmış ölçme araçlarına ihtiyaç duyulmaktadır. Son yıllarda değişen eğitim yönelimleri ölçme araçlarına verilen önemin giderek artmasına neden olmuş ve eğitimcilerin yeni, daha kapsamlı ölçme araçları geliştirmelerine yol açmıştır. Alan yazın incelendiğinde çalışmaların daha çok kavram yanılgılarını belirlemeye yönelik olduğu görülmektedir (Sözbilir ve Kutu, 2008; Wassink ve Sadi, 2016) .

Öğrencilerin başarılarını ölçmek ve sonuçları değerlendirmek için yapılan çalışmalarda sıklıkla iki aşamalı testler, mülakat, sözlü sınav, açık uçlu sorular, doğru yanlış testleri, yazılı yoklamalar, çoktan seçmeli testler, kısa cevaplı testler, eşleştirmeli testler ve boşluk doldurmalı testler kullanılmaktadır (Şimşek, 2007; Ogan Bekiroğlu, 2004). Çoktan seçmeli testler, öğrenci başarısını belirlemek için bir veya daha fazla ünitenin içerisinde yer aldığı bölümlerden oluşan ve işlenilen konuların kapsam geçerliği sağlayacak şekilde çok sayıda sorudan oluşan etkili bir şekilde öğrencilerin öğrenmelerini sorgulayan ve hem kolay hem de anlaşılması güç kavramları ölçme 
olanağı sağlayan günümüzde sıklıkla tercih edilen ölçme araçlarından birisidir (Akbulut, Çepni, 2013). Özçelik (1998)' e göre çoktan seçmeli testler günümüze kadar oluşturulmuş en üstün ölçme aracı olarak alan yazınına geçmiştir. Çoktan seçmeli olarak oluşturulan testler öğrencilerin başarıları belirlemenin yanı sıra kavram yanılgılarını da belirlemek için (Küçükahmet, 2002) kullanılabilecek ölçme araçlarıdır.

Ülkelerin eğitim sistemlerini bağımsız ve nesnel bir şekilde değerlendirmek için çeşitli uluslararası çalışmalar yapılmaktadır. Bu çalışmaların başında Uluslararası Matematik ve Fen Eğilimleri Araştırması (Trends in International Mathematics and Science Study) TIMSS ve Uluslararası Öğrenci Değerlendirme Programı (Programme for International Student Assessment) PISA yer almaktadır. TIMMS, öğrencilerin matematik ve fen alanlarında kazandıkları bilgi ve becerilerin değerlendirilmesine yönelik bir tarama araştırmasıdır (MEB, 2015). 4. ve 8. sinıf düzeyindeki öğrencilere dört yılda bir yapılmaktadır. PISA'da ise zorunlu eğitimin sonunda örgün eğitime devam eden 15 yaş grubundaki öğrencilerin; Matematik okuryazarlığı, Fen Bilimleri okuryazarlığı ve Okuma Becerileri konu alanlarının dışında, öğrencilerin motivasyonları, kendileri hakkındaki görüşleri, öğrenme biçimleri, okul ortamları ve aileleri ile ilgili veriler toplanmaktadır (MEB, 2015). Bu sınavlarda hazırlanan sorular günlük yaşamla ilişkili ve daha üst düzey düşünme becerileri isteyecek şekilde oluşturulmaktadır. Ülkemiz açısından elde edilen sonuçlara bakıldığında genel olarak istenilen seviyede olmadığımızı görmekteyiz. Bu sebepten dolayı yapılan çalışmalarda kullanılan ölçme ve değerlendirme yöntemlerinin gözden geçirilerek yeniden yapılandırılması ihtiyaç duyulmaktadır (Bulunuz ve Bulunuz, 2013). Bu düşünceden hareketle çalışmada, ABBT ile günlük hayatla ilişkili uluslararası sınavlardaki soru formatına benzer bir test geliştirilmesi amaçlanmıştır.

\subsection{Araştırmanın amacı}

Araştırmanın amacı sekizinci sınıf Madde ve Endüstri ünitesi Asitler ve Bazlar konusuna yönelik hazırlanan Asit ve Baz Başarı Testi (ABBT)'den elde edilen nicel verilerle geçerlik ve güvenirlik analiz yapmaktır.

\section{Yöntem}

Bu çalışmada sekizinci sınıf öğrencilerinin Asitler ve Bazlar konusunda yönelik başarılarını ölçmek amacıyla bir başarı testi geliştirilmiş, testin geçerlik ve güvenirlik incelemeleri yapılmıştır. Asit-Baz Başarı Testi (ABBT) hazırlanırken MEB (2018) tarafından belirlenen kazanımlar göz önünde bulundurulmuş, çoktan seçmeli soruların kazanımlarla ilişkili olmasına dikkat edilmiştir. Test hazırlanırken ilk olarak madde havuzu oluşturulmuş, ardından ABBT'nin kapsam geçerliğini sağlamak amaciyla uzman görüşlerine başvurulmuştur. Uzman görüşlerinin ardından gerekli düzenlemeler yapılmış ardından ABBT'nin pilot çalışması sonucunda elde edilen verilerin madde analizi yapılmıştır. Madde analizinin ardından ABBT'nin geçerlik ve güvenirlik değeri hesaplanmış, testten çıkarılması gereken maddeler belirlendikten sonra teste son hali verilmiştir.

\section{1.Örneklem}

Bu çalışmanın evrenini 8.sınıf öğrencileri, örneklemini 2018-2019 öğretim yılında Adana ve Aksaray illeri Merkez ilçelerindeki ortaokullarda eğitimine devam eden 212 sekizinci sınıf öğrencisi oluşturmaktadır. Bu çalışmada, katılımcıların okullarının belirlenmesinde amaçlı örneklem yöntemlerinden ölçüt örnekleme kullanılmıştır. Ölçüt örnekleme yöntemi, daha önce sınırları belirlenmiş bir sıra ölçütü sağlayan bütün durumların araştırılmasıdır (Yıldırım ve Şimşek, 2013). Ölçütler daha önceden hazırlanmış olabileceği gibi araştırmacı tarafından da oluşturulabilmektedir (Yıldırım ve Şimşek, 2013). Araştırmada, testin uygulanması için belirlenen temel kriter öğrencilerin ilköğretim sekizinci sınıfta eğitimine devam ediyor olması olarak belirlenmiştir. 


\subsection{Veri Analizi}

\subsubsection{ABBT'nin Geliştirilme Süreci}

Çalışmada, asit baz konusuna yönelik ABBT geliştirilmesi sürecinde geçerliğin ve güvenirliğin sağlanması için bazı adımlar planlanmış ve planlanan bu adımlar gerçekleştirilmiştir. ABBT geliştirilmesi sürecinde; madde havuzunun oluşturulması, uzman görüşüne başvurulması, ön çalışmanın yapılması, asıl uygulama geçerlik ve güvenirlik çalışması için yapılan istatistiksel analizlerdir. ABBT’nin geliştirilme süreci aşağıda detaylı bir şekilde açıklanmıştır.

\section{A.) Madde havuzu oluşturma süreci}

ABBT testi oluşturulurken öncelikle 2018 Fen Bilimleri Dersi Öğretim Programında yer alan kazanımlar belirlenmiştir. Kazanımlar doğrultusunda TIMMS, PISA, MEB örnek yayın soruları ve halihazırda mevcut yayınına devam eden sekizinci sınıf deneme kitaplarında yer alan sorular incelenerek yazarlar tarafından her kazanıma yönelik sorular hazırlanmıştır. Hazırlanan test soruları kazanımlar ile ilişkilendirilerek bir belirtke tablosu oluşturulmuştur. Kazanımlar incelendiğinde örtük bir şekilde bilimsel süreç becerilerininde yer aldığı görülmüş ve bundan dolayı Bloom Taksonomisine uygun olarak bir beceri tablosu oluşturulmuştur. Taslak olarak hazırlanan 21 sorudan oluşan ABBT (EK-1), Kazanım belirtke tablosu (Tablo 1), Beceri tablosu (Tablo 2) belirlenen kriterler doğrultusunda (Tablo 3) uzman olarak kabul edilen üç kimya eğitimcisi akademisyenin görüşlerine başvurulmuştur. İncelenen soruların genellikle açık uçlu, durum belirleyici ve çoktan seçmeli maddelerden oluştuğu görülmüştür. Madde havuzu oluşturulurken dört seçenekten oluşan 21 test sorusu yazılmıştır.

Tablo 1: Asitler ve Bazlar konusu kazanım-soru ilişkilendirme tablosu

\begin{tabular}{|c|c|}
\hline Kazanımlar & Soru Numaraları \\
\hline F.8.4.4.1. Asit ve bazların genel özelliklerini ifade eder. & $1,2,3,4$ \\
\hline F.8.4.4.2. Asit ve bazlara günlük yaşamdan örnekler verir. & $5,6,7,8,9$ \\
\hline $\begin{array}{l}\text { F.8.4.4.3. Günlük hayatta ulaşılabilecek malzemeleri asit- } \\
\text { baz ayracı olarak kullanır. }\end{array}$ & 10 \\
\hline $\begin{array}{l}\text { F.8.4.4.4. Maddelerin asitlik ve bazlık durumlarına ilişkin } \\
\text { pH değerlerini kullanarak çıkarımda bulunur. }\end{array}$ & 11,12 \\
\hline $\begin{array}{l}\text { Konu ile ilgili deney yolu ile çıkarımlarda bulunmaları } \\
\text { sağlanır. }\end{array}$ & \\
\hline $\begin{array}{l}\text { F.8.4.4.5. Asit ve bazların çeşitli maddeler üzerindeki } \\
\text { etkilerini gözlemler. }\end{array}$ & $7,13,14,15,21$ \\
\hline $\begin{array}{l}\text { F.8.4.4.6. Asit ve bazların temizlik malzemesi olarak } \\
\text { kullanılması esnasında oluşabilecek tehlikelerle ilgili } \\
\text { gerekli tedbirleri alır. }\end{array}$ & 16,17 \\
\hline $\begin{array}{l}\text { F.8.4.4.7. Asit yağmurlarının önlenmesine yönelik çözüm } \\
\text { önerileri sunar. }\end{array}$ & $18,19,20$ \\
\hline $\begin{array}{l}\text { Asit yăgmurlarının oluşum sebepleri ve sonuçlarına } \\
\text { değinilir. }\end{array}$ & \\
\hline
\end{tabular}

Tablo 1'de 2018 Fen Öğretim programından yer alan asitler ve bazlar konusu kazanımları ve ABBT için hazırlanan maddelerden oluşturulan belirtke tablosu yer almaktadır 
Tablo 2: Bloom taksonomisi beceri-soru ilişkilendirme tablosu

\section{Bloom Taksonomisi}

Olgusal Bilgi

Kavramsal Bilgi

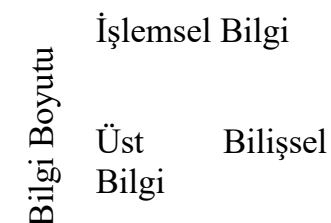

Tablo 2'de ABBT için hazırlanan maddelerin Bloom taksonomisinde yer aldığı boyutların ilişkisi görülmektedir.

Tablo 3: ABBT değerlendirme tablosu
Bilişsel Süreç Boyutu

Hatırlama Anlama Uygulama Çözümleme Değerlendirme Yaratma

$1,2,3,12, \quad 4$
17,19

$5,6,8$,

9,12

$7,14,15$

11,16

10,21

13

20

18

\section{Uygun}

Uygun değil

Açıklama

1. Soru, ilgili kazanımı ölçmede yeterlidir.

2. Sorunun yalnız bir doğru cevabı vardır.

3. Çeldiricilerin elenmesi, ilgili kazanımın öğrenilmiş olduğunu göstermektedir.

4. Çeldiriciler, doğru cevabı bulmada ipucu içermemektedir.

5. Soru kökünde verilen bilgiler, bilimsel gerçeklere uygundur.

6. Soru kökünde gerekli bilgiler verilmiştir.

7. Çeldiriciler doğru cevap olmayacak ifadelerdir.

8. Soru ilgili yaş ve sınıf düzeyine uygundur.

9. Görseller, uygun şekilde yerleştirilmiştir.

Tablo 3'de uzman görüşü için hazırlan sorular yer verilmiştir. Bu sorular ile uzmanlardan ABBT için belli sınırlar içinde maddelerin değerlendirilmesini yapması istenmiştir.

\section{B.) Uzman görüşüne başvurulması süreci}

Uzman görüşlerinden alınan dönütler sonrasında test soruları üzerinde düzeltmeler ve değişiklikler yapılmıştır. Düzeltme yapılan sorular iki Türkçe öğretmeni, iki Fen Bilimleri öğretmeni ile paylaşılmış ve uygunluğu ile ilgili görüşlerine başvurulmuştur. Alana yönelik hazırlanan testlerin geçerliğini sağlamak için uzman görüşüne başvurulması bilimsel çalışmalarda sıkça başvurulan bir yöntemdir.

\section{C.) Ön çalışmanın yapılması}

ABBT'nin pilot çalışmasında bir devlet okulunda yer alan 10 sekizinci sınıf öğrencisine uygulanmıştır. Pilot çalışma sırasında öğrencilerin soruları anlama düzeyi, zorluk derecesinin tespiti ve görünüş geçerliğini sağlamak amaçlanmıştır. Pilot çalışma sonrasında bazı sorular üzerinde düzeltmeler yapılmış soru sayısında bir değişiklik olmamıştır. 


\section{D.) Asıl uygulama geçerlik ve güvenirlik çalışmaları}

Çoktan seçmeli ve dört seçenekli olarak hazırlanan ABBT 21 maddeden oluşmaktadır ve toplamda 212 öğrenciye uygulanmıştır. Testten elde edilen veriler SPSS 23.0, ITEMAN 3.0 ve FACTOR uygulamaları ile analiz edilmiştir. Testler SPSS 23.0 programında analiz edilirken doğru seçenek için " 1 " çeldiriciler için ise "0" şeklinde kodlanmıştır. ITEMAN 3.0 ile analiz edilirken programın çalışma şekline bağlı olarak seçenekler doğrudan girilmiş daha sonra elde edilen sonuçlarda doğru cevapları " 1 " yanlış cevapları " 0 " kabul ederek değerlendirme yapmıştır. Öğrencilerin testten aldıkları toplam puanlar hesaplanarak geçerlik ve güvenirlik çalışmaları yapılmıştır. Bu doğrultuda aşağıdaki analizlere yer verilmiştir:

I. Madde güçlük indeksi

II. Madde ayırt edicilik indeksi

III. Alt-Üst grup ortalama farkına dayalı madde analizi

IV. ITEMAN analiz sonuçları

V. Kuder-Richardson-20 (KR-20) güvenirlik katsayıs1

VI. $\quad$ FACTOR analiz sonuçları

\section{Bulgular}

Bu bölümde 8. sınıf asitler ve bazlar konusuna yönelik hazırlanan ABBT'nin test ve madde analizine ait bulgulara yer verilmiştir.

Tablo 4: Madde analiz bulgular1

\begin{tabular}{lll} 
Madde No & Madde Ayırt Edicilik İndeksi (rjx) & Madde Güçlük İndeksi (Pj) \\
\hline 1 &, 42 &, 77 \\
2 &, 32 &, 59 \\
3 &, $26^{*}$ &, 62 \\
4 &, $20^{*}$ &, 42 \\
5 &, $23^{*}$ &, 59 \\
6 &, 37 &, 44 \\
7 &, $21^{*}$ &, 58 \\
8 &, 41 &, 60 \\
9 &, 35 &, 50 \\
10 &, 53 &, 47 \\
11 &, 40 &, 53 \\
12 &, $24^{*}$ &, 17 \\
13 &,$- 08^{* *}$ &, 34 \\
14 &, $26^{*}$ &, 27 \\
15 &, $12^{* *}$ &, 35 \\
16 &, 32 &, 70 \\
17 &, 35 &, 58 \\
18 &, 49 &, 65 \\
19 &, 35 &, 56 \\
20 &, 45 &, 41 \\
21 &, 37 &, 77 \\
\hline
\end{tabular}

*Madde ayırt edicilik indeksi 0,20-0,29 arasında yer alan maddeler

**Madde ayırt edicilik indeksi 0,20 altında yer alan maddeler 
Tablo 5: Alt Grup-Üst Grup Ortalama Farkına Dayalı Madde Analizi T-testi Sonuçları

\begin{tabular}{|c|c|c|c|c|c|c|c|}
\hline $\begin{array}{l}\text { Bağımlı } \\
\text { değişken }\end{array}$ & Grup & $\mathbf{N}$ & $\overline{\mathbf{X}}$ & SS & Sd & $\mathbf{t}$ & $\mathbf{p}$ \\
\hline \multirow[t]{2}{*}{ Madde 1} & Alt grup & 57 &, 4737 &, 50375 & 112 & $-7,375$ & , 000 \\
\hline & Üst grup & 57 &, 9825 &, 13245 & 63,706 & $-7,375$ &, 000 \\
\hline \multirow[t]{2}{*}{ Madde 2} & Alt grup & 57 &, 5614 &, 50063 & 112 & $-6,139$ &, 000 \\
\hline & Üst grup & 57 &, 9825 &, 13245 & 63,802 & $-6,139$ & ,000 \\
\hline \multirow[t]{2}{*}{ Madde 3} & Alt grup & 57 &, 4035 & ,49496 & 112 & $-4,528$ & ,000 \\
\hline & Üst grup & 57 &, 7895 & ,41131 & 108,369 & $-4,528$ &, 000 \\
\hline \multirow[t]{2}{*}{ Madde 4} & Alt grup & 57 &, 4035 & ,49496 & 112 & $-4,271$ & ,000 \\
\hline & Üst grup & 57 &, 7719 &, 42332 & 109,369 & $-4,271$ &, 000 \\
\hline \multirow[t]{2}{*}{ Madde 5} & Alt grup & 57 &, 1404 & ,35044 & 112 & $-5,678$ &, 000 \\
\hline & Üst grup & 57 &, 5965 & ,49496 & 100,869 & $-5,678$ &, 000 \\
\hline \multirow[t]{2}{*}{ Madde 6} & Alt grup & 57 &, 3158 & ,46896 & 112 & $-7,778$ & ,000 \\
\hline & Üst grup & 57 &, 8947 & ,30962 & 97,025 & $-7,778$ & ,000 \\
\hline \multirow[t]{2}{*}{ Madde 7} & Alt grup & 57 & ,2982 &, 46155 & 112 & $-4,914$ & ,000 \\
\hline & Üst grup & 57 &, 7193 &, 45334 & 111,964 & $-4,914$ & ,000 \\
\hline \multirow[t]{2}{*}{ Madde 8} & Alt grup & 57 &, 1404 &, 35044 & 112 & $-9,940$ &, 000 \\
\hline & Üst grup & 57 &, 8246 & ,38372 & 111,090 & $-9,940$ & ,000 \\
\hline \multirow[t]{2}{*}{ Madde 9} & Alt grup & 57 & ,2982 &, 46155 & 112 & $-7,314$ &, 000 \\
\hline & Üst grup & 57 &, 8596 &, 35044 & 104,460 & $-7,314$ &, 000 \\
\hline \multirow[t]{2}{*}{ Madde 10} & Alt grup & 57 & ,0877 &, 28540 & 112 & $-12,895$ &, 000 \\
\hline & Üst grup & 57 &, 8596 &, 35044 & 107,590 & $-12,895$ &, 000 \\
\hline \multirow[t]{2}{*}{ Madde 11} & Alt grup & 57 & ,2456 &, 43428 & 112 & $-8,307$ & , 000 \\
\hline & Üst grup & 57 &, 8596 &, 35044 & 107,215 & $-8,307$ & , 000 \\
\hline \multirow[t]{2}{*}{ Madde 12} & Alt grup & 57 & ,2807 & ,45334 & 112 & $-5,697$ & ,000 \\
\hline & Üst grup & 57 &, 7544 &, 43428 & 111,794 & $-5,697$ & ,000 \\
\hline \multirow[t]{2}{*}{ Madde 13} & Alt grup & 57 &, 1579 & ,36788 & 112 & ,261 & ,795* \\
\hline & Üst grup & 57 &, 1404 &, 35044 & 111,737 & ,261 & ,795* \\
\hline \multirow[t]{2}{*}{ Madde 14} & Alt grup & 57 &, 1404 &, 35044 & 112 & $-5,678$ &, 000 \\
\hline & Üst grup & 57 &, 5965 & ,49496 & 100,869 & $-5,678$ &, 000 \\
\hline \multirow[t]{2}{*}{ Madde 15} & Alt grup & 57 & ,2281 & ,42332 & 112 & $-2,424$ & ,017* \\
\hline & Üst grup & 57 & ,4386 &, 50063 & 108,990 & $-2,424$ & ,017* \\
\hline \multirow[t]{2}{*}{ Madde 16} & Alt grup & 57 & ,0877 & ,28540 & 112 & $-6,723$ & , 000 \\
\hline & Üst grup & 57 &, 5965 & ,49496 & 89,531 & $-6,723$ & ,000 \\
\hline \multirow[t]{2}{*}{ Madde 17} & Alt grup & 57 &, 4035 & ,49496 & 112 & $-7,121$ & ,000 \\
\hline & Üst grup & 57 & ,9298 &, 25771 & 84,284 & $-7,121$ &, 000 \\
\hline \multirow[t]{2}{*}{ Madde 18} & Alt grup & 57 &, 1930 &, 39815 & 112 & $-11,730$ &, 000 \\
\hline & Üst grup & 57 & ,9298 & ,25771 & 95,918 & $-11,730$ &, 000 \\
\hline \multirow[t]{2}{*}{ Madde 19} & Alt grup & 57 &, 3684 & ,48666 & 112 & $-6,889$ &, 000 \\
\hline & Üst grup & 57 & ,8947 & ,30962 & 94,952 & $-6,889$ & ,000 \\
\hline \multirow[t]{2}{*}{ Madde 20} & Alt grup & 57 & ,2632 & ,44426 & 112 & $-8,806$ & ,000 \\
\hline & Üst grup & 57 &, 8947 & ,30962 & 100,016 & $-8,806$ & , 000 \\
\hline \multirow[t]{2}{*}{ Madde 21} & Alt grup & 57 &, 1754 & ,38372 & 112 & $-8,241$ & , 000 \\
\hline & Üst grup & 57 &, 7895 & ,41131 & 111,465 & $-8,241$ & ,000 \\
\hline
\end{tabular}


Tablo 4 incelendiğinde ölçekte yer alan 21 maddenin 13'ünün madde ayırt edicilik indeksi (rjx) 0,40 ve üzerinde yer almaktadır. Madde ayırt edicilik indeksi, ölçülmek istenen davranışın elde edilip edilemediği hakkında araştırmacılara fikir vermek için kullanılır. Bir maddenin ayırt edicilik indeksi -1 ile +1 arasında değer alırken değerin "0" olması maddenin ayırt edici olmadığını gösterir. Madde ayırt edicilik indeksi 0,19 ve altında bir değer alırsa maddelerin testten çıkarılması, 0,20-0,29 arasinda yer alan maddelerin düzeltilebilmesi ya da zorunlu durumlarda kullanılabileceği, 0,30- 0,39 arasındaki maddelerin yeterince iyi maddeler olduğu, 0,40 ve üzerinde değer alan maddelerin ise çok iyi maddeler olduğu şeklinde yorumlanır (Büyüköztürk vd., 2012; Karslı ve Ayas, 2013; Tosun ve Taşkesenligil, 2011). Bu sonuç doğrultusunda ABKBT'nin ayırt ediciliği değerler yüksek bulunmuştur. Ayrıca “*” işaretlenen altı madde araştırmacılar tarafindan tekrar incelenmiş ve ölçekte kalmalarına karar verilmiştir. “**” olarak işaretlenen iki madde araştırmacılar tarafindan kontrol edilmiş ve ölçekten çıkarılmasına karar verilmiştir. Madde güçlük indeksi $(\mathrm{Pj})$, testte yer alan her bir maddenin doğru cevaplanma oranını gösterir ve " 0 " ile " 1 " arasında değer alır. Maddelerin aldığ 1 değerler sıfıra yaklaştıkça o maddenin zorlaştı̆̆ını gösterirken, bire yaklaştıkça maddenin kolaylaştığını gösterir. Madde analizi sonucunda maddelerin madde güçlük indekslerinin 0,20 ile 0,80 arasında olması ve testin ortalama güçlük indeksinin ise 0,50 civarında olması çalışmalarda aranan bir özelliktir (Büyüköztürk, Çakmak, Akgün, Karadeniz ve Demirel, 2012; Tosun ve Taşkesenligil, 2011). Ölçekteki maddelerin madde güçlük indeksleri 0,50 ve civarında yer aldığı için madde güçlük indeksinin yüksek olduğu tespit edilmiştir. Tablo 5'de görüldüğü üzere ABBT 'nin yapı geçerliğinin sağlanması için \%27 alt ve üst gruplara ait veriler belirlenerek ikiye ayrılmıştır. Bu analiz sonucunda iki grup arasındaki farkın anlamlığına bakılmış ve bağımsız gruplar t-testi uygulanmıştır. Bağımsız t-testi sonuçları gereği, Sig (2-tailed) değeri 0,05'den küçük olan maddelerin testte yer alması, 0,05'ten büyük olan maddelerde ise anlamlı bir fark olmadığından testten çıkarılması şeklinde yorumlanmıștır (Yıldırım ve Şimşek, 2013). Ölçekten çıkarılmasına karar verilen maddelerin anlamlılık değerlerine bakılmış ve $p<0.05$ büyük olduğu görülmüştür. Ölçekten çıkarılmasına karar verilen maddelerin belirtke tablosunda yer aldığı kazanımlara bakılmış ve konunun kapsam geçerliğini etkilemediği görülmüştür. Aşağıda ölçekten çıkarılmasına karar verilen sorılar ver almaktadır

13.) Mehmet Bey arazisinde verimliliği arttırmak için her geçen yıl daha fazla gübre kullanmaktadır. Ancak köylerine gelen ziraat mühendisi topraktaki $\mathrm{pH}$ değerinin 5-8 arasında olması gerektiğini, kullanılan gübre miktarının çok fazla olduğunu, bu şekilde devam etmesi durumunda arazisindeki verimin giderek azalacağını söylemiştir. Arazide yapılan ölçümlerden sonra toprağın pH değeri 3,9 olduğu bulunmuştur. Ziraat mühendisinin bu sözlerinden sonra Mehmet Bey nasıl bir yol izlemelidir?

A) Arazisini daha fazla sulamalıdır.

B) Toprağında kireçli gübre kullanmalıdır.

C) Toprağında asitlik oranı yüksek gübre kullanmalıdır

D) Toprağının pH değerini arttıracak gübrelerden kullanmalıdır.
15.) Sıkça kemik ağrılarından şikâyet eden Ahmet Bey'e yapılan tahliller sonucunda kemik erimesi(osteoporoz) teşhisi konmuştur. Doktoru, özellikle asitli içecek (kola, gazoz) ve yiyeceklerden uzak durması gerektiğini söylemiştir.

Sizce doktor neden asitli yiyecek ve içeceklerden uzak durması gerektiğini söylemiştir?

A) Asitli yiyecek ve içecekler kemikleri eritir.

B) Kola içerisinde yer alan kafein maddesi kemik erimesine neden olur.

C) Asitli yiyecek ve içecekler kemiklerden Ca miktarının azalmasına neden olur.

D) Asitli yiyecek ve içeceklerde kullanılan aşırı tatlandırıcılar kemiklerde olumsuz etkiler yaratır. 
Tablo 6: ITEMAN analiz sonuçları

\begin{tabular}{ll} 
Özellik & Değer \\
\hline Madde sayısı & 21 \\
Uygulanan kişi sayısı & 212 \\
Ortalama & 10,953 \\
Varyans & 17,420 \\
Standart sapma & 4,174 \\
Çarpıklık & $-0,098$ \\
Basıklık & $-0,797$ \\
Testten alınan minimum puan & 2,00 \\
Testten alınan maksimum puan & 19,00 \\
Ortanca & 11,00 \\
Cronbach's Alpha güvenirlik katsayısı & 0,765 \\
SEM & 2,022 \\
Ortalama güçlük & 0,522 \\
Ortalama ayırt edicilik & 0,415 \\
Çift serili ortalaması & 0,534
\end{tabular}

*Ölçekten çıkarılmasına karar verilen sorular $(\mathrm{p}<0.05)$

Tablo 6 incelendiğinde ortalama madde güçlük indeksi 0,522 olarak bulunmuştur. Ölçeğin ortalama güçlükte olduğunu ve ideale yakın bir değer aldığı görülmektedir. Ölçeğin ortalama ayırt edicilik indeksi ise 0,415 bulunmuş ve maddelerin bilen ile bilmeyen öğrencileri ayırt edebileceği şeklinde yorumlanmıştır. Madde analizlerinden elde edilen verilerden sonra ölçeğin iç tutarlılık katsayısını belirlemek için Kuder-Richardson 20 (KR-20) güvenirlik katsayısı hesaplanmıştır. KR20 formülüne göre hesaplama yapmak, testteki her bir maddenin aynı değişkeni ölçtüğü ve testin ölçtüğü şeyi aynı özelliklere sahip olduğu varsayımına dayanır (Tekin, 2007). ABBT'nin iç tutarlılık katsayısı hesaplanmış ve 0,732 olarak bulunmuştur.

$$
K R_{20}=\frac{K}{K-1}\left[1-\frac{\sum p q}{S_{x}^{2}}\right]
$$

\section{FACTOR yapı geçerliği analiz sonuçları}

Yapı geçerliği, testin ölçülmek istenen davranış bağlamında soyut bir kavramı (faktörü) doğru bir şekilde ölçebilme derecesini gösterir (Büyüköztürk, 2009). Yapı geçerliğinin belirlenmesi için 1-0 şeklinde puanlanan testlerde tetrakorik kolerasyon matrisi üzerinden açımlayıc1 faktör analiz yapılması uygun görülmektedir (Uebersax, 2008). Tetrakorik kolerasyon katsayısı ise iki kategorili yapay süreksiz iki değişkenin arasındaki ilişkiyi belirlemek için kullanılır (Baykul ve Güzeller, 2014). 


\begin{tabular}{|c|c|c|}
\hline \multicolumn{3}{|c|}{ Tablo 7: Faktör yükleri } \\
\hline Bağımlı değişken & Faktör yükü & Ortak varyans \\
\hline Madde 1 & 0,669 & 0,448 \\
\hline Madde 2 & 0,483 & 0,233 \\
\hline Madde 3 & 0,384 & 0,147 \\
\hline Madde 4 & $* 0,280$ & 0,079 \\
\hline Madde 5 & 0,301 & 0,091 \\
\hline Madde 6 & 0,517 & 0,267 \\
\hline Madde 7 & $* 0,292$ & 0,085 \\
\hline Madde 8 & 0,579 & 0,335 \\
\hline Madde 9 & 0,512 & 0,262 \\
\hline Madde 10 & 0,725 & 0,525 \\
\hline Madde 11 & 0,552 & 0,305 \\
\hline Madde 12 & 0,352 & 0,124 \\
\hline Madde 13 & $* 0,175$ & 0,031 \\
\hline Madde 14 & 0,379 & 0,144 \\
\hline Madde 15 & $* 0,145$ & 0,021 \\
\hline Madde 16 & 0,433 & 0,188 \\
\hline Madde 17 & 0,585 & 0,343 \\
\hline Madde 18 & 0,713 & 0,509 \\
\hline Madde 19 & 0,560 & 0,314 \\
\hline Madde 20 & 0,669 & 0,447 \\
\hline Madde 21 & 0,560 & 0,314 \\
\hline
\end{tabular}

*Ölçekten çıkarılmasına karar verilen sorular $(<0,30)$

Tablo 7 görüldüğü üzere testte yer alan maddelerin faktör yükleri belirlenmiştir. Maddelerin geçerli olduğu varsayılması için faktör yüklerinin minimum değerinin 0,30 'un üzerinde olması beklenir (Tabachnick ve Fidell, 2007). Analiz sonucunda testin 4,7,13,15'inci maddeleri 0,30 değerinin altında kalmıştır ancak 4. ve 7. maddeler araştırmacıları tarafından sınır değere yakın olması ve kapsam geçerliğini düşürmemek için teste yer almaya devam etmiştir, bununla birlikte 13.ve 15. maddelerin testten çıkarılmasına karar verilmiştir.

Tablo 8: Geçerlik ve güvenirlik katsayıları

\begin{tabular}{ll} 
Bartlett's statistic & $2043,1(\mathrm{df}=210 ; \mathrm{P}=0,000010)$ \\
\hline Kaiser-Meyer-Olkin (KMO) test & 0,778 \\
\hline
\end{tabular}

Tablo 8'de görüldüğü gibi KMO değeri 0-1 arasında değerler almaktadır, bu değer 0,50 ile 0,60 arsında ise kötü; 0,60 ile 0,70 arasında ise zayıf; 0,70 ile 0,80 arasında ise orta; 0,80 ile 0,90 arasında ise iyi ve 0,90 üzerinde ise mükemmel yorumu yapılır (Baran, 2018; Tavşancıl, 2005). Testin KMO değeri 0,778 olarak hesaplanmış ve orta düzeyde olduğu tespit edilmiştir. Barlett's statistic 2043,1 tespit edilmiştir ve testin yer alan verilerin normal dağıldığını göstermektedir $(\mathrm{P}=$ $0,000010)$.

Bir test için hesaplanan güvenirlik katsayısı değerinin 0,80 ile 1,00 arasında olması ölçme aracının yüksek derecede güvenilir olduğuna, 0,60 ile 0,80 arasında olması oldukça güvenilir olduğuna, 0,60 ve altında ise güvenilirliğin düşük veya çok düşük olduğunu işaret etmektedir (Kalayc1, 2008). Testin analizi sonucunda güvenirlik katsayısı 0,891 olarak hesaplanmıştır ve yüksek derecede güvenilir bir test olduğu ortaya çıkmıştır.

GFI değeri 0 ile 1 arasında değerler almaktadır. GFI'nın 0.90'1 üzerinde yer alması ise mükemmel bir model göstergesi olarak kullanılmaktadır. Araştırmada Goodness of Fit Index (GFI) 
değeri 0.905 olarak hesaplanmıştır. $\mathrm{Bu}$ durum ise gözlenen değişkenlerin arasında yeterli kovaryansın hesaplandığı göstermektedir (Ayyıldız, Cengiz ve Ustasüleyman, 2006).

\section{Tartışma ve Sonuç}

Bu çalışma, sekizinci sınıf fen bilimleri dersi madde ve endüstri ünitesinde yer alan asitler ve bazlar konusuna yönelik dört seçenekli olarak 19 maddeden oluşturulmuş ve güncel öğretim programına uygun olarak hazırlanmıştır. Ölçeğin kuramsal çerçevesi MEB tarafından ücretsiz olarak verilen ders kitabı, PISA, TIMSS sınavları, sınıf düzeyine uygun olarak hazırlanan halihazırda yayına devam eden test kitapları ve yazarların özgün olarak hazırladığı maddelerden oluşmaktadır. Ölçeğin geçerliğini sağlamak için alanında uzman akademisyenlere ve MEB'da görevli fen bilimleri ögretmenlerinden görüş alınmıştır. Ölçeğin kapsam geçerliğini sağlamak için belirtke tablosu oluşturulmuş ve uzman görüşü alınarak hangi hedef davranışlara ve bilişsel düzeye uygun olduğuna karar vermeye çalışılmıştır. Son yıllarda yapılan araştırmalarda ölçekler hazırlanırken geçerlik ve güvenirlik çalışmaları ile beraber yenilenen Bloom Taksonomisine de yer verilmektedir. $\mathrm{Bu}$ şekilde maddelerin daha anlaşııır ve ayrıntılı olarak sınıflandırılması sağlanmıştır (Çepni vd., 2007). Ayrıca Bloom taksonomisi bilişsel alan sınıflaması, maddelerin amaçlarının açıkça ve gözlenebilir olmasına olanak sağlanması nedeniyle eğitim alanında sıklıkla kullanılmaktadır (Ayvacı, Türkdoğan, 2009).

ABBT’nin çoktan seçmeli maddelerden oluşması bir dezavantaj olarak görülebilir. Ancak Akbulut ve Çepni'ye (2013) göre çoktan seçmeli olarak hazırlanan ölçek maddeleri puanlamada kolaylık, nesnellik ve başarı ölçen merkezi sınavlarda büyük yarar sağlayacağı tespit edilmiştir. Çoktan seçmeli olarak hazırlanan ölçeklerde üst düzey becerileri ölçen maddeler oluşturmak ve öğrencilerin bu yönde düşünmesini sağlamak için hazırlanan sorular uluslararası olarak hazırlanan ölçme araçlarına benzer şekilde oluşturulmalıdır.

Alanyazında ki benzer ölçek oluşturma çalışmaları doğrudan bilgiyi ölçmeye yönelik olarak hazırlanmıştır. Ancak öğrencilerin genellikle zihinsel modellemede yeterli olduğunu fakat asit ve bazlarla ilgili örnek verirken, deney tasarlarken ve günlük yaşamlarında karşılaştıkları asit ve bazları tanımlarken sorunlar yaşadığı görülmektedir (Çelikler ve Harman, 2015). ABBT ile oluşturan maddeler bu sorunları temele alarak günlük yaşama yönelik düşünmelerini sağlamayı amaçlamıştır. Asitler ve bazlar konusuna yönelik hazırlanan ölçme ve değerlendirme çalışmalarında ABBT ölçme aracı olarak eğitimciler tarafından kullanılabileceği öngörülmektedir. Testin geçerliği ve güvenirliği sağlanırken SPSS 23.0, ITEMAN 3.0 ve FACTOR uygulamalarından yararlanılmıştır. SPSS 23.0 ile, teste yer alan maddelerin t-testi sonuçlarına bakılmış ve testten çıkarılması gereken sorular belirlenmiştir (Tablo 5). Ayrıca maddelerin ayırıcılık ve güçlük indeksleri hesaplanarak testte amacina hizmet etmeyen sorular belirlenmiştir (Tablo 4). ITEMAN 3.0 ile testte yer alan maddelerin ortalama madde ayırıcıllk ve madde güçlük indeksleri ve KR-20 değerini elde etmek için değerler hesaplanmıştır (Tablo 6). Son olarak FACTOR uygulaması ile tetrakorik kolerasyon katsayısı hesaplanmış ve testin yapı geçerliği belirlenmiştir (Tablo 7,8).

\section{Öneriler}

- Benzer ölçek hazırlama süreci takip edilerek öğretim programına uygun olarak farklı sınıf ve konulara yönelik başarı testi geliştirilebilir.

- $\quad$ Hazırlanan ABBT ile daha sonraki aşamalarda öğrencilerin başarısını belirlemekle beraber kavram yanılgılarını da ortaya çıkarmak için kullanılabilir.

- Hazırlanan kaynak kitaplarda daha açık bir dil tercih edilerek öğrencilerin soruları doğru anlaması sağlanalabilir. 
- Kullanılan test geliştirme aşamaları daha sonraki yapılacak olan çalışmalar için bir yol gösterici olarak kullanılabilir.

katkıda bulunulabilir.

$\mathrm{Bu}$ çalışma farklı örneklem gruplarında kullanılarak geçerlik ve güvenirliğine

\section{Kaynakça}

Andersson, B. (1986). Pupilse explanations of some aspects of chemical reactions. Science Education, 70 (5), 549-563, https://doi.org/10.1002/sce.3730700508

Akbulut, H. İ. ve Çepni, S. (2013). Bir üniteye yönelik başarı testi nasıl geliştirilir? İlköğretim 7. sinıf kuvvet ve hareket ünitesi. Amasya Üniversitesi Eğitim Fakültesi Dergisi, 2(1), 18-44, https://doi.org/10.17679/inuefd.108600

Avc1 Bölek, H. (2012). Genel kimya dersinde asitler ve bazlar konusunda örnek olaya dayalı ögrenme yönteminin ögrencilerin akademik başarısına etkisi. Yüksek Lisans Tezi, Dokuz Eylül Üniversitesi Eğitim Bilimleri Enstitüsü, İzmir, https://doi.org/10.14527/9786050022001.04

Ayvacı, H. Ş., ve Türkdoğan, A. (2010). Yeniden yapılandırılan Bloom taksonomisine göre fen ve teknoloji dersi yazılı sorularının incelenmesi. Türk Fen Eğitimi Dergisi,7(1), 13-25, https://doi.org/10.17121/ressjournal.302

Ayyıldız, H., Cengiz, E., ve Ustasüleyman, T. (2006). Üretim ve pazarlama bölüm çalişanlari arasi davranişsal değiş̧kenlerin firma performansi üzerine etkisine ilişkin yapisal bir model önerisi. Muğla Üniversitesi Sosyal Bilimler Enstitüsü Dergisi, (17), 21-38, https://doi.org/10.31795/baunsobed.645486

Baran, H. (2018). Açıköğretim sınavlarının faktör yapısının incelenmesi: Uluslararası İlişkiler Kuramları-I dersi örneği. Açıkögretim Uygulamaları ve Araştırmaları Dergisi, 4(1), 23-46.

Bradley, J. D., \& Mosimege, M. D. (1998). Misconceptions in acids and bases: A comparative study of student teachers with different chemistry backgrounds. South African Journal of Chemistry, 51, 137-145.

Bennett, J., Lubben, F. \& Hogarth, S. (2007). Bringing science to life: A synthesis of the research evidence on the effects of context-based and STS approaches to science teaching. Science Education, 91(3), 347-370, https://doi.org/10.1002/sce.20186

Bulunuz, M. ve Bulunuz, N. (2013). Fen öğretiminde biçimlendirici değerlendirme ve etkili uygulama örneklerinin tanıtılması. Türk Fen Eğitimi Dergisi, 10(4), 119-135, https://doi.org/10.17522/nefefmed.83848

Büyüköztürk, Ş. (2009). Sosyal bilimler için veri analizi el kitabı. Pegem Akademi, https://doi.org/10.14527/9789756802748

Canpolat, N., Pınarbaşı, T., Bayrakçeken, S. ve Geban, Ö. (2004). Kimyadaki bazı yaygın yanlış kavramalar. Gazi Üniversitesi Gazi Eğitim Fakültesi Dergisi, 24(1), 135-146, https://doi.org/10.17152/gefd.10834

Cooper, C., \& Pearson, P. (2012). A genetically optimized predictive system for success in general chemistry using a diagnostic algebra test. Journal of Science Education and Techology, 21 (1), 197 - 205, https://doi.org/10.1007/s10956-011-9318-z

Corcoran, T. B., Mosher, F. A., \& Rogat, A. D. (2009). Learning progressions in science: An evidence-based approach to reform. New York, NY: Columbia University, Teachers 


$\begin{array}{lllll}\text { College, Center } & \text { on } \quad \text { Continuous } & \text { Instructional } & \text { Improvement, } \\ \text { https://doi.org/10.12698/cpre.2009.rr63 }\end{array}$

Çavdar, O., Okumuş, S., Alyar, M ve Doymuş, K. (2017). Asitler ve bazlar konusunun anlaşılmasına farklı yöntemlerin etkisi. Necatibey Ĕgitim Fakültesi Elektronik Fen ve Matematik Eğitimi Dergisi (EFMED), 11(2), 383-408, doi: https://doi.org/10.17522/balikesirnef.373415

Çelikler, D. ve Harman, G. (2015). Fen bilgisi öğrencilerinin asit ve bazlarla ilgili zihinsel modellerinin analizi. Mustafa Kemal Üniversitesi Sosyal Bilimler Enstitüsü Dergisi, 12 (32), 433-449.

Çepni, S., Bayrakçeken, S., Yılmaz, A., Yücel, C., Semerci, Ç., Köse, E., Sezgin, F., Demircioğlu, G. ve Gündoğdu, G. (2007). Ölçme ve Değerlendirme (1. Bask1). Pegem A Yayıncılık, https://doi.org/10.11616/basbed.vi.455855

Çökelez, A. (2015). Fen eğitiminde model ve modelleme öğretmenler, öğretmen adayları ve öğrenciler: Alanyazın taraması. Turkish Studies, 10(15), 255-272, https://doi.org/10.7827/turkishstudies.8707

Demirci, Ö. ve Özmen, H. (2012). Zenginleştirilmiş bir öğretim materyalinin öğrencilerin asit ve bazlarla ilgili anlamalarına etkisi. Amasya Üniversitesi Eğitim Fakültesi Dergisi, 1(1), 117, https://doi.org/10.17860/efd.70389

Demircioğlu, F. N., Özdemir, S., Özmen, H., Cındıl, T. ve Yıldız, M. F. (2012, Haziran). Fen bilgisi ögretmen adaylarının asit-baz kavramlarıyla ilgili yanılgılarının tespiti. X. Ulusal Fen Bilimleri ve Matematik Eğitimi Kongresi, 27-30 Haziran 2012, Niğde Üniversitesi, Niğde, https://doi.org/10.17522/balikesirnef.541641

Griffiths A.K., \& Preston, K.R. (1992). Grade-12 students" misconceptions relating to fundamental characteristics of atoms and molecules. Journal of Research in Science Teaching, 29(6), 611-628, https://doi.org/10.1002/tea.3660290609

Kalaycı, Ş. (2008). Spss uygulamalı çok değişkenli istatistik teknikleri, Asil Yayın Dağıtım.

Karslı, F. ve Ayas, A. (2013). Fen ve teknoloji dersi öğretmen adaylarının bilimsel süreç becerilerinin ölçülmesine ilişkin bir test geliştirme çalışması. Türk Fen Eğitimi Dergisi, 10(2), 66-84, https://doi.org/10.17522/balikesirnef.276920

Küçükahmet, L. (2002). Öğretimde planlama ve değerlendirme (13. Baskı). Nobel Yayın Dağıtım.

Milli Eğitim Bakanlığı MEB, (2015). Uluslararası ögrenci değerlendirme programı PISA 2015 ulusal raporu. Ankara: M.E.B. Ölçme Değerlendirme ve Sinav Hizmetleri Genel Müdürlüğü. content/uploads/2014/11/PISA2015 UlusalRapor.pdf, https://doi.org/10.17051/ilkonline.2018.419357

Milli Eğitim Bakanlığı MEB, (2015). Uluslararası Matematik ve Fen Eğilimleri Araştırması TIMMS 2015 ulusal raporu. Ankara: M.E.B. Ölçme Değerlendirme ve Sınav Hizmetleri Genel Müdürlüğü. content/uploads/TIMSS_2015_Ulusal_Rapor.pdf, https://doi.org/10.14527/9786053186359.03

Milli Eğitim Bakanlığı (MEB) (2018). Fen Bilimleri Dersi Öğretim Programı (İlkokul ve Ortaokul 3,4,5,6,7 ve 8. sinif, $\quad$ http://mufredat.meb.gov.tr/Dosyalar/201812312311937FEN\%20BILIMLERI\%20ÖĞRETIM\%20PROGRAMI2018.pdf, https://doi.org/10.16992/asos.14271 
Ogan Bekiroğlu, F. (2004). Ne kadar Başarıll? Klasik ve Alternatif Ölçme- Değerlendirme Yöntemleri ve Fizikte Uygulamalar (1. bask1). Nobel Yayın Dağıtım.

Özmen, H., Demircioğlu, G., \& Coll., R.K. (2007). A comparative study of the effects of a concept mapping enhanced laboratory experience on Turkish high school students' understanding of acid-base chemistry, International Journal of Science and Mathematics Education, 7, 124, https://doi.org/10.1007/s10763-007-9087-6

Pabuçcu, A. ve Geban, Ö. (2015). 5E öğrenme döngüsüne göre düzenlenmiş uygulamaların asitbaz konusundaki kavram yanılgılarına etkisi. Abant İzet Baysal Üniversitesi Eğitim Fakültesi Dergisi, 15(1), 191-206, https://doi.org/10.17240/aibuefd.2015.15.1-5000128602

Saunders, W.L., \& Shepardson, D. (1987). A comparison of concrete and formal science instruction upon science achievement and reasoning ability of sixth grade students. Journal of Research in Science Teaching, 24 (1), 39-51, https://doi.org/10.1002/tea.3660240105

Smith, K.J., \& Metz, P.A. (1996). Evaluating student understanding of solution chemistry through microscopic representations. Journal of Chemical Education, 73(3), 233-235. doi: https://doi.org/10.1021/ed073p233.

Sözbilir, M., \& Kutu, H. (2008). Development and current status of science education research in Turkey. Essays in Education, Special Issue, 1-22.

Tavşancıl, E. (2005). Tutumların Ölçülmesi ve SPSS ile Veri Analizi. (2. Baskl). Nobel Yayınları.

Tekin, H. (2007). Eğitimde ölçme ve değerlendirme (19.basım). Yargı Yayınevi.

Tosun, C. ve Taşkesenligil, Y. (2011). Revize edilmiş Bloom'un taksonomisine göre çözeltiler ve fiziksel özellikleri konusunda başarı testinin geliştirilmesi: Geçerlik ve güvenirlik çalışması. Kastamonu Eğitim Dergisi, 19(2), 499-522, https://doi.org/10.24106/kefdergi.4008

Tsaparlis, G. (1997). Atomic and molecular structure in chemical education. Journal of Chemical Education, 74(8), 922-925.

Uebersax J.S. (2008). Introduction to the tetrachoric and polychoric correlation coefficients, https://john-uebersax.com/stat/tetra.htm

Wassink, F. K., ve Sadi, Ö. (2016). Türkiye'de Fen Bilimleri Eğitimi Yönelimleri: 2005 ile 2014 Y1lları Arası Bir İçerik Analizi. Ilkogretim Online, 15(2), https://doi.org/10.17051/io.2016.05687

Yadigaroğlu, M., Demircioğlu, G. ve Demircioğlu, H. (2017). Fen bilgisi öğretmen adaylarının kimya bilgilerini günlük hayatla ilişkilendirebilme düzeyleri. Ege Eğitim Dergisi, 18(2), 795-812. doi: https://doi.org/10.12984/egeefd.310426

Yıldırım, A. ve Şimşek, H. (2013). Sosyal bilimlerde nitel araştırma yöntemleri (10. Baskı). Seçkin Yayıncilik. 


\section{Asit ve Baz Başarı Testi}

Aşağıdaki tabloda asit ve bazların genel özelliklerinden bazıları verilmiştir. Birinci ve ikinci soruları bu tabloya göre cevaplayınız.

\begin{tabular}{|l|l|l|}
\hline $\begin{array}{l}\text { 1.Tatları } \\
\text { acıdır }\end{array}$ & $\begin{array}{l}\text { 2.Kırmızı } \\
\text { turnusol } \\
\text { kağıdının } \\
\text { rengini maviye } \\
\text { çevirirler. }\end{array}$ & $\begin{array}{l}\text { 3. Ele kayganlık } \\
\text { hissi verirler. }\end{array}$ \\
\hline $\begin{array}{l}\text { 4.pH } \\
\text { cetvelinde } \\
0-7 \\
\text { arasında } \\
\text { yer alırlar. }\end{array}$ & $\begin{array}{l}\text { 5.Tatları } \\
\text { ekşidir. }\end{array}$ & $\begin{array}{l}\text { 6.Metallerle } \\
\text { tepkimeye } \\
\text { girerek } \mathrm{H}_{2} \text { gazı } \\
\text { açığa çıarırlar. }\end{array}$ \\
\hline $\begin{array}{l}\text { 7.Mavi } \\
\text { turnusol } \\
\text { kağıdını } \\
\text { kırmızıya } \\
\text { çevirirler. }\end{array}$ & $\begin{array}{l}\text { 8.pH } \\
\text { cetvelinde 7- } \\
\text { yer alırlar. }\end{array}$ & $\begin{array}{l}\text { 9.Cam ve plastik } \\
\text { kaplarda } \\
\text { saklanılmalıdır. }\end{array}$ \\
\hline
\end{tabular}

1.) Tabloya göre asitlerin genel özellikleri ile ilgili olan numaraların yer aldığı seçenek hangisidir?
A) $1,2,4,5,6$
B) $2,4,6,7,9$
C) $4,5,6,7,8$
D) $4,5,6,7,9$ hangisidir?
A) $1,2,3,5$
B) $1,2,3,8$
C) $2,3,5,8$
D) $3,5,6,7$

2.) Tabloya göre bazların genel özellikleri ile ilgili olan numaraların yer aldığı seçenek

3.) Aşağıda verilen özeliklerden hangileri asit ve bazların ortak özelliğidir.
III. Tahriş edici özelliğe sahiptirler

IV. $\mathrm{CI}_{2}$ gazı açı̆̆a çıkarırlar
A) I- II- III
B) I-II-IV
C) II- III- IV
D) I-III- IV

4.) Fen bilimleri dersi sınavına hazırlanan Ayşe, asit-baz konusundaki soruları çözerken zorluk yaşamaktadır. Aşağıda bazı maddelerin kimyasal ve günlük yaşamdaki kullanılan adları verilmiştir. Ayşe, seçeneklerden hangisini işaretlerse maddenin kimyasal adı ve günlük yaşamdaki adını doğru eşleştirmiş olur?

Kimyasal adı Günlük yaşam adı
1.HCI
a. tuz ruhu
2. $\mathrm{NaOH}$
b. zaç yağ 1
3. $\mathrm{H}_{2} \mathrm{SO}_{4}$
c. kezzap
4. $\mathrm{HNO}_{3}$
d. sudkostik

A)

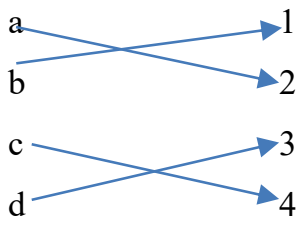

C)

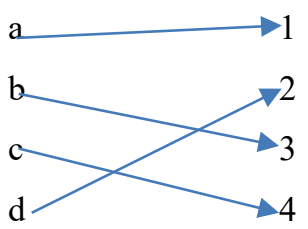

B)

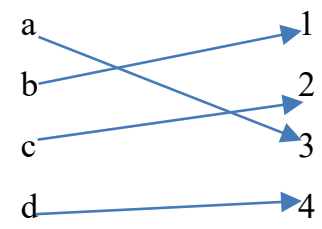

D)

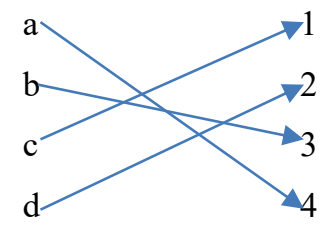

I. Turnusol kâğıdına etki etme

II. Sulu çözeltilerinin elektriği iletmesi

5.) Ali, köydeki bahçelerinde dolaşırken karıncaların yuvalarından çıktığını ve yuvanın 
etrafinda bulunan boş sirke şişesi, temizlik maddeleri kutusu ve gübre torbalarının olduğu yöne doğru ilerlediklerini görmüştür. Ali fen bilimleri dersinde bu ürünlerin asit ve baz içerikli olduğunu öğrenmiş ancak bu maddelerin hangisinin asit hangisinin baz olduğunu sürekli karıştırmıştır. Ali'nin yerinde siz olsanız karıştırmamak için hangi seçeneği işaretlerdiniz?

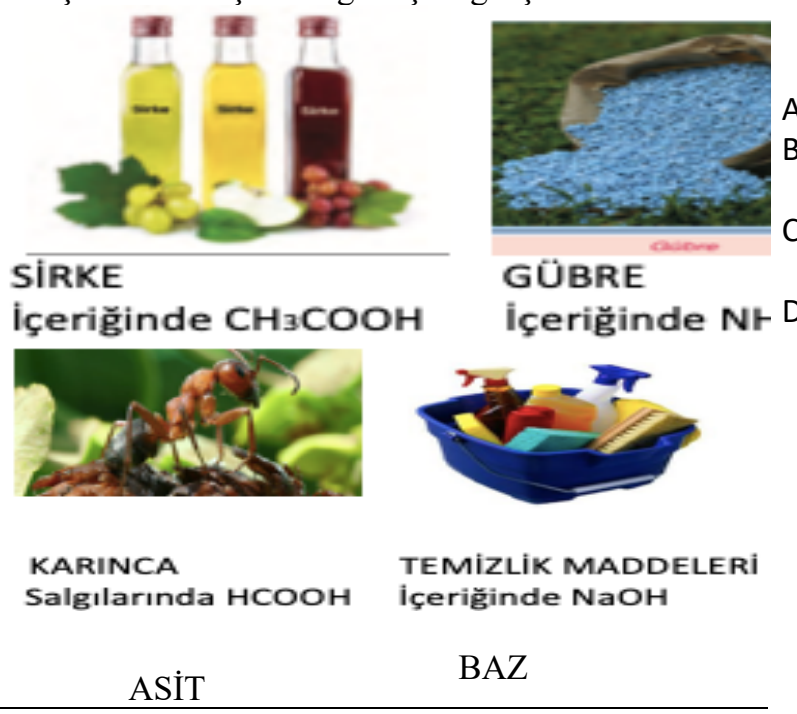
A) Sirke
Karınca salg1sı
B) Gübre
Sirke
C) Temizlik maddeleri
Gübre
D) Karınca salgisı
Temizlik maddeleri

6.) Selma mutfakta yıkadığı portakal ve elmaları soymaya başlamıştır. İşi bittiğinde bazı meyve parçaları mutfakta ki mermer tezgâh üzerinde kalmıştır. Mutfağa gelen annesi Selma'yı meyveleri bir daha tezgâh üzerinde birakmaması konusunda uyarmıştır. Annesinin Selma'yı uyarmasının sebebi sizce ne olabilir?

A) Meyvelerin sularının mermer tezgâh üzerindeki kirleri aşındırma ihtimali.

B) Meyvelerin sularının mermer tezgâh ile etkileşime girerek kireç oluşturma ihtimali.

C) Meyvelerin sularındaki asidik karakter mermer tezgâh ile kimyasal etkileşime girme ihtimali

D) Meyvelerin sularındaki bazik karakterin mermer tezgâh ile etkileşime girerek tuz oluşturması ihtimali.

7.) Meltem bir gazete haberinde küçük bir çocuğun yanlışlıkla elini asit çözeltisine batırdığını ve elinin yanarak zarar gördüğünü okumuştur. Bir sonraki gün okuldaki fen bilimleri dersinde öğretmeni, cam kaba bir miktar sülfürik asit çözeltisi koymuş ve içerisine bir adet de patates cipsi atmıştır.

Bunu gören Meltem'in aklına hemen okuduğu gazete haberi gelmiş ve ögrretmenine cipsin eriyerek tamamen kaybolacağını söylemiştir.

Meltem'in öğretmenine verdiği cevabı göz önünde bulundurduğunuzda seçeneklerden hangisi doğru olur?

A) Doğru. Kuvvetli asitler her şeyi yakarlar.

B) Kısmen doğrudur. Cips bir miktar zarar görür ancak tamamen yok olmaz.

C) Kısmen yanlıştır. Asit çözeltisinin miktarı arttıkça cips daha fazla zarar görür.

D) Yanlış. Böyle olsaydı günlük hayatta kullandığımız asit ürünleri de bize zarar verirdi.

8.) Hüseyin öğretmen dersinde asit-baz konusunu öğretirken, öğrencilerine günlük hayatta karşılaşılan asit ve bazları tanıtmış ve çeşitli örnekler vermiştir. Hüseyin öğretmen konuyu öğretirken aşağıdaki gibi üç farklı kapta deney düzenekleri hazırlamıştır.

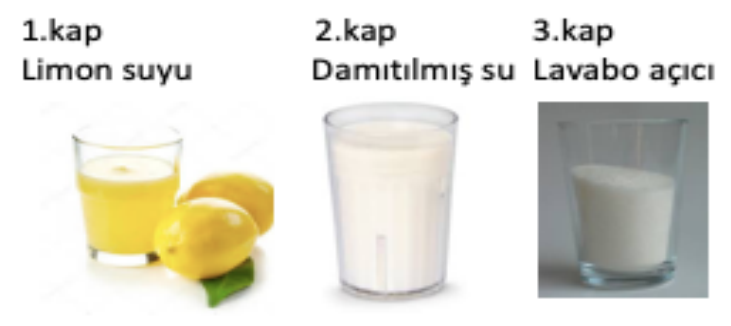

Hüseyin öğretmen öğrencilerine mavi turnusol kâğıdı vererek turnusol kağıtlarını kaplara batırıp çıkardıktan sonra gözlemlemelerini istemiştir. Öğrencilerin gözlemleri sonucunda turnusol kağıtlarında hangi renkler oluşur?

$\underline{1 . k a p} \quad \underline{2 . k a p} \quad$ 3.kap

A) Mavi Kırmızı Renk

değişi

$\mathrm{mi}$

olmaz

B) Kırmızı Mavi $\quad \begin{gathered}\text { Renk } \\ \text { olmaz }\end{gathered}$ değişimi

C) Renk Kırmızı Mavi

değişimi

olmaz

D) Kirmizı

Renk

değişimi 
olmaz

9.) Salih öğretmen, öğrencilerinin asit ve baz çözeltilerinde turnusol kağıdındaki renk değişimini tam olarak öğrenemediklerini fark etmiştir. $\mathrm{Bu}$ nedenle üzerlerinde adları yazılı olmayan çözeltileri sırası ile yan yana koymuştur. Öğrencilerden bir gönüllü seçerek sırası ile mavi turnusol kağıdını kaplara batııр çıkarmasını istemiş ve sonrasında öğrencilerle aşağıdaki durumları gözlemlemişlerdir.

Kullanılan çözeltiler

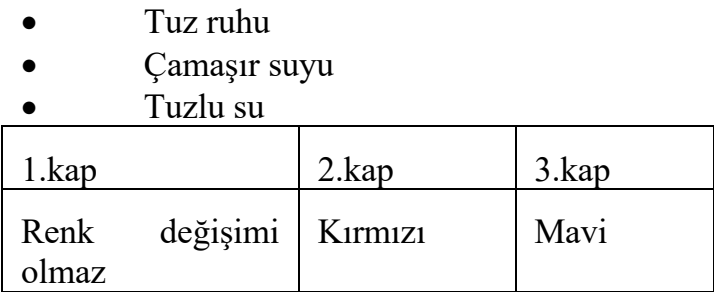

\begin{tabular}{|c|c|c|c|}
\hline & 1.kap & 2.kap & 3.kap \\
\hline A) & Tuz ruhu & $\begin{array}{l}\text { Çamaşır } \\
\text { suyu }\end{array}$ & Tuzlu su \\
\hline B) & Tuzlu su & Tuz ruhu & $\begin{array}{l}\text { Çamaşır } \\
\text { suyu }\end{array}$ \\
\hline C) & $\begin{array}{l}\text { Çamaşır } \\
\text { suyu }\end{array}$ & Tuz ruhu & Tuzlu su \\
\hline D) & $\begin{array}{l}\text { Çamaşır } \\
\text { suyu }\end{array}$ & Tuzlu su & Tuz ruhu \\
\hline
\end{tabular}

10.) Mustafa fen bilimleri dersinde ögretmeninden maddelerin asit ya da baz olup olmadığını indikatörlerdeki renk değişiminden anlaşılabileceğini öğrenmiştir. Öğretmenleri ders sırasında doğal indikatör hazırlama deneyi yapmıştır. Öğretmenleri deney öncesinde, soğan kabuklarını havanda dövmüş, su ile karıştırıp kırmızı bir çözelti elde edilmiştir. Daha sonrasinda;

Küçük bir kaba tuz ruhu (HCI) diğer kaba ise sodyum hidroksit $(\mathrm{NaOH})$ koymuştur. Kaplara hazırlanan ayıraçtan bir miktar ekleyerek öğrencilerinden meydana gelecek değişimi gözlemelerini istemiştir. Gözlemler sonucunda tuz ruhu çözeltisi pembe, sodyum hidroksit çözeltisi ise kahverengi renk almıştır.
Mustafa aynı deneyi evinde bulunan ürünlere de denemeye karar vermiştir. Mustafa'nın aşağıda verilen maddeleri kullanması durumunda maddelerin alacağ 1 renk konusunda verilenlerden hangisi doğru olur?
A) Kahverengi
Kahverengi
B) Kahverengi
Pembe
C) Pembe
Kahverengi
D) Pembe
Pembe

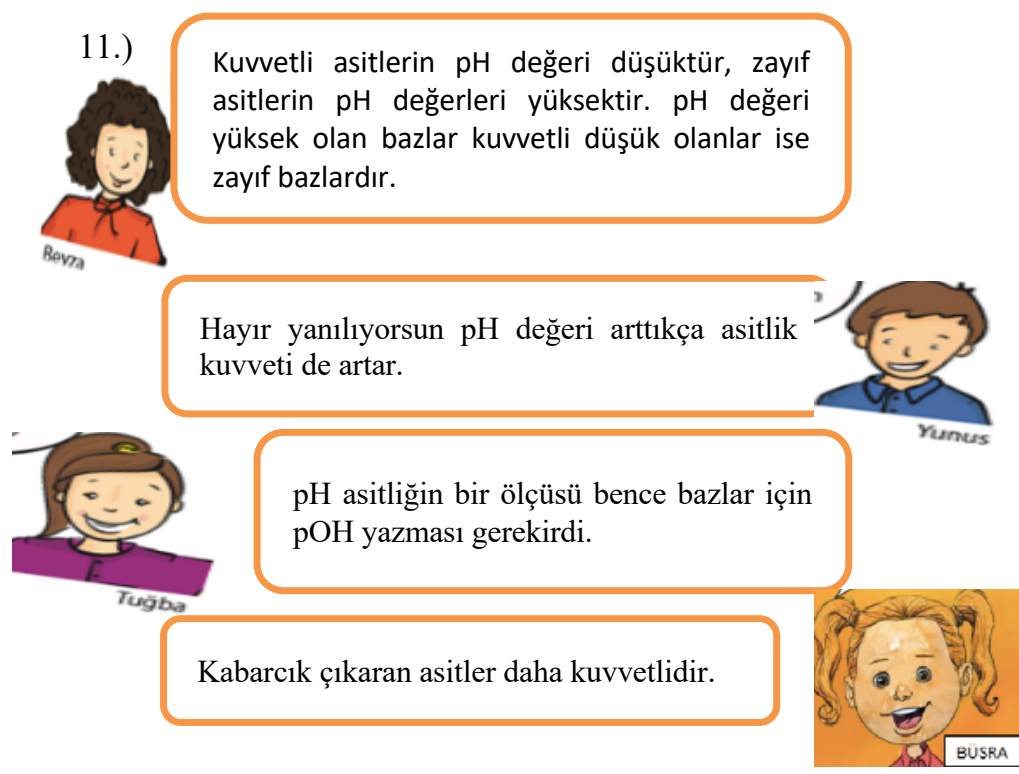

Mehmet teneffüste arkadaşları ile otururken öğretmenlerinin tahtaya yazdığ 1 bazı maddelerin pH değerleri dikkatini çekmiştir. Arkadaşları bu maddelerin $\mathrm{pH}$ cetvelinde nerede yer alacağı ve kuvvetli ya da zayıf oluşu ile ilgili tartışırken aralarında yukarıdaki gibi bir konuşma geçer.

Mehmet arkadaşlarını da dinledikten sonra doğru bir sıralama yaptığına göre;

Sizce hangi arkadaşının cevabı doğrudur?

A) Yunus'un cevabı doğrudur. Çünkü değer ne kadar büyürse o kadar kuvvetlidir asit.

B) Tuğba'nın cevabı doğrudur. $\mathrm{pH}$ içinde ' $\mathrm{H}$ ' var bu nedenle sadece asitleri temsil eder.

C) Büşra'nın cevabı doğrudur. Çünkü asitlerin kuvveti arttıkça kabarcık ve duman çıkarırlar. 
D) Beyza'nın cevabı doğrudur. Asitler 'in $\mathrm{pH}^{\prime} \mathrm{s} 1$ sıfıra yaklaştıkça, bazların ise 14'e yaklaştıkça kuvveti artar.

12.) Aşağıda kimyasal formülleri ve $\mathrm{pH}$ ve $\mathrm{pOH}$ değerleri verilen maddeleri $\mathrm{pH}$ cetveli üzerine yerleştirilmiştir. Sizce hangisi doğrudur?
A) Asitli içecekler dişleri yaktığı için sızıya neden olmuştur.

B) Asitli içeceklerde ki $\mathrm{CO}_{2}$ gazı çıkışı dişleri etkileyerek siziya neden olur.

C) Asitli içecekler diş yapısında $\mathrm{Ca}$ mineralini etkilediği için sızıya neden olur.

D) Asitli içeceklerin içinde ki şeker miktarı çok olduğu için sızıya neden oluştur.

14.)

ÖLDÜREN KARIŞIM TEHLİKE SAÇIYOR!

Türkiye'de özellikle banyo, tuvalet ve mutfak temizliğinde tercih edilen çamaşır suyu ve tuz ruhunun birlikte kullanılması sonucu ortaya çıkan zehirlenme türü olarak kayıtlara geçmiştir.

Uzmanlar, bu iki maddenin karışmasının, gözlerde yanma bulgularıyla ortaya çıkarak ve solunum yoluyla zehirlenmeye yol açtığını belirlemişlerdir. Acil servislere başvuranların hemen hemen hepsinin, 'Temizlik yaparken tuz ruhu döktüm, daha temiz olsun diye üstüne de çamaşır suyu boşalttım ve bir gaz çıktı, nefesim daralmaya başladı: şikayetleri ile geldiklerini söylediler.

Gazete haberini okuyan Recep, böyle bir durum ile karşılaşmamak için sizce ne yapmalıdır?

A) Koruyucu maske ile temizliğe devam etmeli.

B) İki maddeyi dökmeden önce yüzey su ile yıkamalı.

C) Kullanılan iki maddede baz olduğu için birini aside çevirmeli.

D) Maddeler yüzeye döküldükten sonra ortam iyice havalandirmalı

15.) Ali okul laboratuvannda öğretmenine yardım etmektedir. Güvenlik işaretlerinin olduğu etiketleri dolaba yapıştırırken birbirine karıştırmıştır. Buna göre doğru eşleştirme nasıl olmalıdır? a

b

d

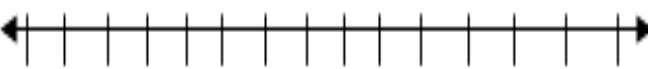

D)

b

c d

a

13.) Bayramda büyükanne ve büyükbabasını ziyarete giden Kübra, ikram edilen tatlı ve şekerleri yemiş, asitli ve gazlı içeceklerden içmiştir. Bir süre sonra dişlerinin sızladığını fark etmiştir. Doktora gittiğinde asitli içeceklerin dişlerine çok fazla zarar verdiğini öğrenmiştir.

Sizce Kübra'nın dişlerindeki sızının sebebi nedir?
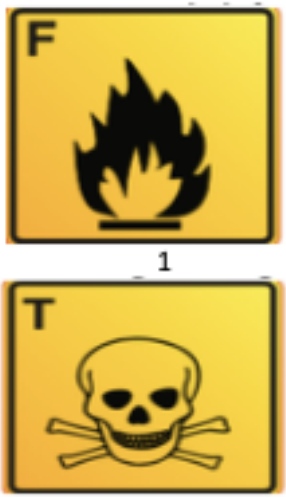

3
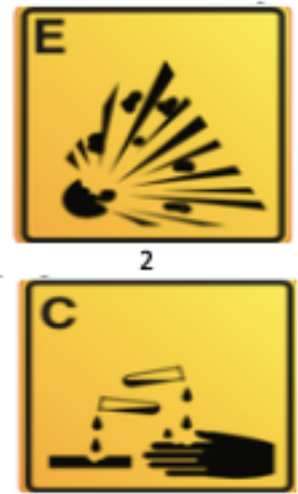

4

\begin{tabular}{|l|c|c|c|c|}
\hline & ZEHIRLI & PATLAYIC & AŞINDIRICI & $\begin{array}{l}\text { ŞIDDETLI } \\
\text { ALEV ALICI }\end{array}$ \\
\hline A) & 1 & 3 & 2 & 4 \\
\hline B) & 3 & 2 & 4 & 1 \\
\hline C) & 2 & 1 & 3 & 4 \\
\hline D) & 3 & 4 & 2 & 1 \\
\hline
\end{tabular}




\section{6. ve 17. soruları aşağıda ki paragrafı okuyarak yanıtlayınız.}

Çeşitli olaylar sonucunda atmosfere yayılan $\mathrm{CO}_{2}$ (karbon dioksit), $\mathrm{SO}_{2}$ (kükürt dioksit) ve $\mathrm{NO}_{2}$ (azot dioksit) gibi gazlar atmosferdeki su ile tepkimeye girerek $\mathrm{H}_{2} \mathrm{SO}_{4}$ (sülfürik asit), $\mathrm{HNO}_{3}$ (nitrik asit), $\mathrm{H}_{2} \mathrm{CO}_{3}$ (karbonik asit) gibi asidik özellikteki bileşikleri oluşturur. Bu tür gazların yağmur, kar, dolu seklinde yeryüzüne yağması asit yağmuru olarak adlandırılır. Yapılan incelemeler sonucunda asit yağmurlarının doğaya, canlılara, insan yapımı bina ve anıtlara verdiği zararların etkilerinin gittikçe arttığ görülmektedir. İstanbul ve Antalya'da yapılan kazılar sonucunda aynı döneme ait olduğu belirlenen tarihi eserler gün yüzüne çıkarılmıştır. Beş yil sonra yapılan araştırmalar sonucunda İstanbul'da bulunan tarihi eserlerde daha çok aşınma olduğu gözlemlenmiştir.

16.) Sizce bu durumun sebebi nedir?

A) İstanbul'da daha çok yağışın olması.

B) Antalya'da daha çok yağışın olması.

C) Antalya'da atmosfere daha fazla gaz salınmaktadır.

D) İstanbul'da atmosfere daha fazla gaz salınmaktadır.

17.) Aşağıdakilerden hangisi asit yağmurlarına karşı alınabilecek önlemlerden birisi değildir?

A) Araçların bakımını zamanında yapmak

B) Kalitesiz kömür ve doğalgaz kullanmak.

C) Toplu taşıma araçlarının tercih edilmesi

D) Yenilenebilir enerji kaynaklarını tercih etmek.

18.) Sanayinin yoğun olduğu bölgelerde asit yağmurlarına rastlanılmaktadır. Asit yağmurları doğrudan çevremizdeki göllere ve denizlere karışırken diğer taraftan tükettiğimiz meyve ve sebzelerde hem verim kalitesini etkilerken hem de insan sağlığını olumsuz yönde etkilemektedir.

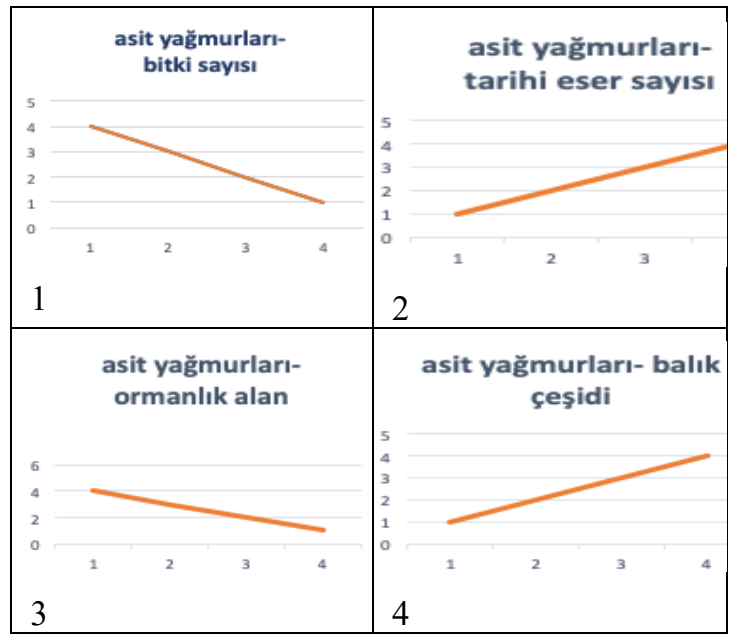

Buna göre yukarıdaki çizilen grafiklerden doğru olana ' $\mathrm{D}$ ' yanlış olana ' $\mathrm{Y}$ ' harfi konulduğunda doğru seçenek hangisi olur?
A) Y, D, D, Y
B) Y, D, Y, D
C) D, Y, Y, D
D) D, Y, D, Y

\section{9. soruyu aşağıdaki paragrafı okuyarak yanitlayız.}

Kimyasal tepkime, bir ya da birkaç maddenin etkileşime girerek yeni bir element veya bileşik grubuna dönüştürülmesi işlemidir. $\mathrm{Bu}$ işlem sırasında renk değişimi, gaz çıkışı ve çökelek oluşumu gibi olaylar gözlemlenebilir.

Maddelerin asit ya da baz oluşunu anlamamızı sağlayan indikatörlerdir. Bunlardan bazıları aşağıda ki tabloda verilmiştir.

\begin{tabular}{|l|l|l|}
\hline İndikatör & Asit & Baz \\
\hline Metil oranj & Kırmızı & Sarı \\
\hline Turnusol & Kırmız1 & Mavi \\
\hline $\begin{array}{l}\text { Brom timol } \\
\text { mavisi }\end{array}$ & Sarı & Mavi \\
\hline Fenolftalein & Renksiz & Pembe \\
\hline
\end{tabular}


19.) Ali öğretmen hazırladığı deney düzeneğinde yukarıdaki tabloda yer alan bazı maddelerin indikatörler ile tepkimeye girmesi sonucunda oluşacak renkleri merak etmektedir. Sizde okları takip ederek doğru seçeneği bulmaya çalışınız.
1 2
3
A) Mavi Sar1 Kırmızı
B) Kırmızı Pembe Kırmızı
C) Renksiz Sarı Kırmızı
D) Mavi Kırmızı Pembe

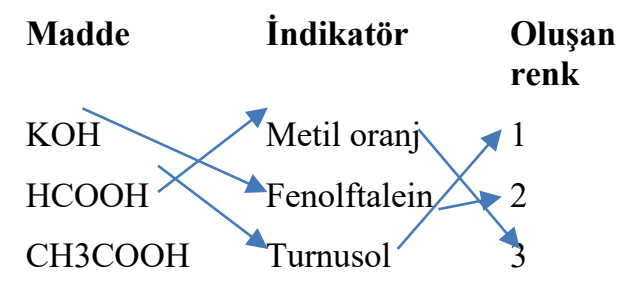

\begin{tabular}{|l|l|}
\hline Soru numaras1 & Cevap \\
\hline 1 & D \\
\hline 2 & B \\
\hline 3 & A \\
\hline 4 & C \\
\hline 5 & D \\
\hline 6 & C \\
\hline 7 & B \\
\hline 8 & D \\
\hline 9 & B \\
\hline 10 & C \\
\hline 11 & D \\
\hline 12 & B \\
\hline 13 & C \\
\hline 14 & D \\
\hline 15 & B \\
\hline 16 & D \\
\hline 17 & B \\
\hline 18 & D \\
\hline 19 & B \\
\hline
\end{tabular}




\section{EK-1}

T.C.

AKSARAY ÜNIVERSITESI

İnsan Araştırmaları Etik Kurulu Kararı

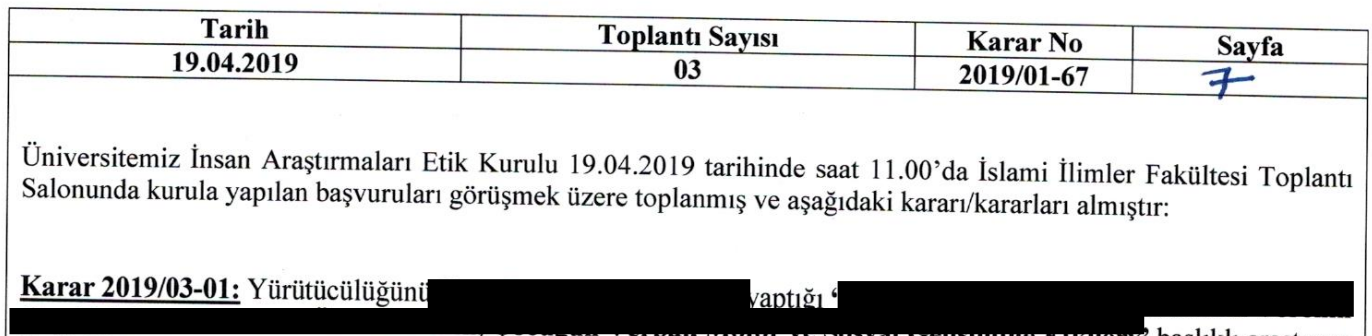

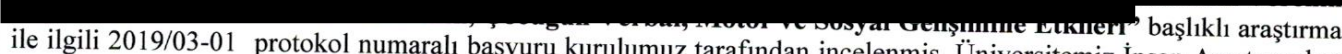
Etik Kurul Yönergesi’nde belirtilen etik ilkele kurulumuz tarafindan incelenmiş, Üniversitemiz İnsan Araştırmaları verilmiștir.
. Karar 2019/03-02: Yürütücülüğünü

\section{n yaptı̆̆}

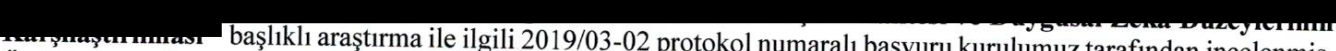
Üniversitemiz İnsan A ŗ üyelerin oy birliği ile karar verilmisti Karar 2019/03-03: Yürütücülüğünü yaptı̆̆ 1 .

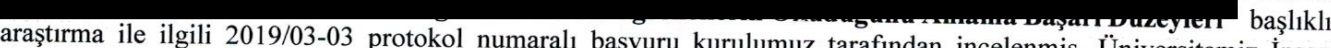
Arsşırmalar Ȩniversitemiz İnsan Araştırmaları Etik Kurul Yönergesi'nde belirtilen etik ilkelere uygun olduğuna, toplantıya katılan üyelerin oy birliği
ile karar verilmiştir.

Karar 2019/03-04: Yürütücülüğünü _ _ vantıŏı_

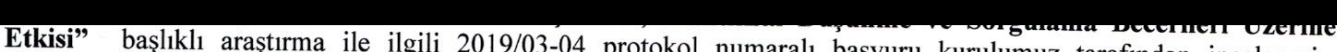
Üniversitemiz İnsan Araștırmaları Etik Kur Yarulumuz tarafından incelenmis, üyelerin oy birliği ile karar verilmiştir.

Karar 2019/03-05: Yürütücülüğünü Dr. Öğr. Üyesi Mustafa YADİGAROĞLU'nun yaptığı “ 8. Sınıf Asit ve Baz Konusuna Yönelik Teknoloji Destekli Rehber Materyal Geliştirilmesi ve Etkililiğinin Araştırılmașı” başlıklı araştırma ile ilgili 2019/03-05 protokol numaralı bașvuru kurulumuz tarafından incelenmiş, Üniversitemiz İnsan Araştırmaları Etik Kurul Yönergesi'nde belirtilen etik ilkelere uygun olduğuna, toplantıya katılan üyelerin oy birliği ile karar verilmiştir.

Karar 2019/03-06: Yürü̈tücülï̈ø̆ïnïi başvuru kurulumuz tarafından incelenmiş, Üniversitemiz İnsan Araştırmaları Etik Kurul Yönergesi'nde belirtilen etik ilkelere uygun olduğuna, toplantıya katılan üyelerin oy birliği ile karar verilmiștir.

Karar 2019/03-07: Yürütücülüğünü __on yaptığ başlıklı araştırma ile ilgili 2019/03-07 protokol numaralı başvuru kurulumuz tarafından incelenmiş, Üniversitemiz İnsan Araştırmaları Etik Kurul Yönergesi'nde belirtilen etik ilkelere uygun olduğuna, toplantıya katılan üyelerin oy birliği ile karar verilmiştir.

Karar 2019/03-08: Yürütücülüğünü $\quad$ nın yaptığı

başlıklı araștırma ile ilgili 2019/03-08 protokol numarah başvuru kurulumuz tarafından incelenmiş, Üniversitemiz İnsan Araştırmaları Etik Kurul Yönergesi'nde belirtilen etik ilkelere uygun olduğuna, toplantıya katılan üyelerin oy birliği ile karar verilmiştir.

Karar 2019/03-09: Yürütücülüğünü

numaralı başvuru kurulumuz tarafından " başlıklı araştırma ile ilgili 2019/03-09 protokol numaralı başvuru kurulumuz tarafından incelenmiş, Üniversitemiz İnsan Araştırmaları Etik Kurul Yönergesi'nde belirtilen etik ilkelere uygun olduğuna, toplantıya katılan üyelerin oy birliği ile karar verilmiştir.

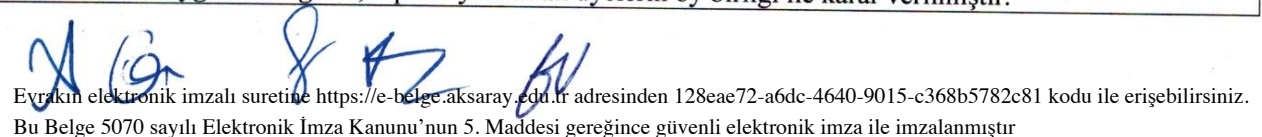

www.turkishstudies.net/education 